\title{
The Fight Against UNFAIR COMPETITION IN POLAND IN THE YEARS 1918-1939
}

\author{
TOMASZ DOLATA*
}

I.

At the time of the restoration of its independence (11.11.1918), Poland "inherited" provisions in force in the field of unfair competition that had been instituted by invading countries. They consisted of radically different juridical solutions. This was the basis for the protection of both formal and theoretical constructions. The only common factor linking the legislation of the occupying countries was the fact that all, to a lesser or greater extent, were the manifestations of some protection against unfair competition.

In the formerly Prussian area, the Act of 07.06.1909 on combating unfair competition (Gesetz gegen den unlauteren Wettbewerb) was in force. ${ }^{1}$ This Act, apart from containing a broader catalogue of acts of unfair competition than the previous law, contained in $\S 1$ a general clause banning all acts of unfair competition. This clause is of fundamental importance for the entire Act, because it defined conduct constituting unfair competition. ${ }^{2}$ German solutions had a great impact on the development of other European laws, including Polish legislation in this area. ${ }^{3}$

Many laws regulating unfair competition in Polish lands formerly included in the territory of the Austrian annexation were in force. In the Austrian legal system a whole range of acts indirectly and partly affecting the fight against this phenomenon functioned. The principal legislative acts

DOI: $10.2478 /$ wrlae-2013-0017

${ }^{*}$ LLM, PhD; Assistant Professor; University of Wroclaw, Faculty of Law, Administration and Economics, Institute of the History of the State and Law; tomek-dolata@wp.pl

1 The law replaced the previous law on unfair competition - Gesetz zur Bekämpfung des unlauteren Wettbewerbes of 27.05.1896. The Act of 27.05.1896 was the world's first legal act regulating the issue of unfair competition by way of statute. Despite some doubts raised by doctrine, the German legislature decided on a casuistic citation in the text of the act of all the most glaring and common forms of unfair competition. Economic freedom and the accompanying competitive struggle resulted in the emergence of new, unregulated acts of unfair competition, which under the Act of 1896 could not be controlled. Another very important factor revealing the weakness of the world's first law on unfair competition was a lack of even a general definition of unfair competition.

${ }^{2}$ See in detail: T Dolata, 'Zwalczanie nieuczciwej konkurencji na ziemiach polskich do 1926 roku' (2005) 2758 Acta Universitatis Wratislaviensis, Prawo CCXCIV 199 - 205.

${ }^{3}$ Like Germany, with the help of a special act decided to combating unfair competition, among other legislatures: Norway (Law of 1922), Austria (Law of 1923), Czechoslovakia (Law of 1924) and Yugoslavia (Law of 1930). 
governing various aspects of unfair competition were: the Austrian Civil Code of 1811 (ABGB), the Austrian Commercial Code of 1861, the Law on limited liability companies of 06.03.1906, the Law on trading assistants of 16.01.1910, the Law on sales of 16.01.1895, the Law on copyright of 26.12.1895 and the Law on the protection of inventions (Patent Act) of 11.01.1897. ${ }^{4}$ Dispersion of the provisions relating to unfair competition in a variety of acts did not exert a positive infulence on the fight against this phenomenon. The overall regulation of this matter in a single instrument was not decided upon by the Austrian legislature until the Law of 26.09.1923 Gesetz gegen den unlauteren Wettbewerb. This act was not applicable in Poland, so it did not have a direct impact on combating unfair competition in our country.

In the territories of the former Russian annexation, as in the former Austrian partition, there was no single law on combating unfair competition. There were provisions in existance directed only against certain forms of unfair competition. Analyzing the legislation on the lands of the former Russian annexation, one can see a duality of legal practice. ${ }^{5}$ This resulted from the fact that in the former Kingdom of Poland, protection against unfair competition was primarily based on appropriate application of the provisions of the Napoleonic Code of torts (Article 1382 and Article 1383 N.C.). Supplementarily, definitions of property contained in the Code (Article 544 N.C.) were applied. In this model, the premises characterizing noncontractual liability (damage and fault) were used. The basis for damage was fault at the creation of that damage. Such an understanding of the issue provided the right to request an injunction that would inhibit acts causing damage or threatening to do so. Juridical solutions in force in the former Congress Kingdom were based entirely on the French model. ${ }^{6}$ Polish judicial practice in the Congress Kingdom, however, did not use the provisions of the Napoleonic Code to create its own model for countering unfair competition.

Entirely different legal standards were used to combat manifestations of unfair competition in eastern Poland, where the basis for protection against this phenomenon consisted of the provisions on tort (Article 574 and Article 684) in 1832, vol. 10, part 1 of the Russian Civil Code (Swod Zakonow).

\footnotetext{
${ }^{4}$ See in detail: Dolata (n 2) $205-210$.

${ }^{5}$ A different legal structure was used to combat unfair competition in the areas of former Congress Kingdom, and a different one in eastern Poland. The rules generally applicable across the whole of the Russian partition, in offering quite effective protection against manifestations of unfair competition, constituted the criminal penalties contained in the Code Tagancew of 1903 (Article 356 and Article 621)

${ }^{6}$ France was the first country to take up the fight against unfair competition. The primary principle in the French legal system was the establishment of commercial and industrial liberty contained in the Act of March 2, 1791, according to which everything that was not expressly prohibited was permitted. Accordingly, the French argued that every honest entrepreneur could acquire a maximum volume of customers, who became his clientele. In this way, establishing the general liability of damages (contained in Article 1382 and Article 1383 N.C.), French case law of unfair competition drew from the literal wording of the aforementioned articles of the Napoleonic Code. With time, a potent and versatile set of rules and standards was created that effectively repressed unfair competition. The essence and the only criterion for the recognition of action for unfair competition was a breach of a legally protected interest, which in the French system was the clientele - "achalandage". By the term "achalandage" we should understand the general relations between the trader and his customers, clients. The French doctrine considered the sum of these relations as a matter of property, and on this basis constructed the subjective right called "droit d'achalandage".
} 
Liability for damage sustained determined the existence of a fault on the part of the perpetrator and the causal link between the damage and the act of the perpetrator. In addition, Russian law containted a prohibition on commercial competition outlawing engagment in commercial activities competing with one's employer (Article 16 of the Russian Law System, vol. 11, part 2). Given the country's relatively underdeveloped industrial and trade sectors, Russian legislation of the time did not include a law regulating the issue of dishonesty in trade nor one fully protecting the merchants functioning in the slowlydeveloping economy. Of all the systems present in occupied Poland, the fight against unfair competition was at its least-developed legislative level in the Russian-annexed region. However, the existing legislation in the former Congress Kingdom should be assessed positively, which, due to the creative evolution of court practices, lead to the most comprehensive model of combating unfair competition - one based a on civil-law protection scheme. ${ }^{7}$

\section{II.}

After regaining independence in 1918, a dramatic process of industrial development and trade expansion began in Poland. Native entrepreneurs began to compete among themselves for goods and services. An economic competition model should be based on competition on quality, prices and other desirable features offered by consumer goods. Meanwhile, those struggling to attract the widest range of customers were often led to using ethically reprehensible measures, which the law could not tolerate. ${ }^{8}$ It was necessary to encompass competition in a certain legal framework, as the continual economic struggle for clients should not affect the rights of businesses or consumers. Ignoring the problem of unfair competition by failing to enact special statutory provisions could have lead to the collapse of trade and industry, which in the absence of integrity and reliability could not function. ${ }^{9}$ Polish lawyers and economists of the time were well aware of the fact that modern rules of commercial law would enable the country to develop and grow. In addition, merchants complained about the problem of unfair competition. $^{10}$

Poland was obliged to enact and implement laws on unfair competition by virtue of its international commitments. ${ }^{11}$ In 1918, Poland signed the Treaty on National Minorities, which in Article 19 required Poland to join the International Convention of Paris of 20.05.1883 concerning the

\footnotetext{
${ }^{7}$ Dolata (n 2) $210-213$.

${ }^{8}$ General justification of the draft law on unfair competition, (1926) 2448 Sejm Print 5

${ }^{9}$ ibid 5.

${ }^{10}$ J Weiss, 'Jak umoralnić nasze kupiectwo?' (1927) 1 Świat Kupiecki 8 - 9. In the face of the crisis in the entire merchant class, Polish merchants appealed to their ethics and traditions - T Andrzejewski, 'Etyka i tradycja kupiecka' (1926) 27 Świat Kupiecki 585 - 587.

11 See: E Dąbrowski, Nieuczciwe współzawodnictwo (1929) Warsaw 119; K Głębocki, 'Uwagi z powodu ustawy: „O zwalczaniu nieuczciwej konkurencji”” (1926) 43 Gazeta Sądowa Warszawska 585; M Mayzel, 'O zwalczaniu nieuczciwej konkurencji' (1926) 5 Przegląd Prawa Handlowego 193; I Rosenblüth, 'Egzekucja na przedsiębiorstwie' (1928) 12 Przegląd Notarialny 75; F Zoll, 'Projekt ustawy o zwalczaniu nieuczciwej konkurencji a sprawa kredytu realnego dla przedsiębiorców’ (1927) 3 Ruch Prawniczy, Ekonomiczny i Socjologiczny 125.
} 
protection of industrial property. ${ }^{12}$ Poland signed the Paris Convention ${ }^{13}$, in which Article 10 bis imposed on all signatories the obligation to ensure effective protection against unfair competition. An international conference with a mandate to revise the Convention's principles and including the participation of delegates from Poland was held in Hague in 1925, during which a more direct and particular commitment to the former Article 10 bis was undertaken. ${ }^{14}$ Moreover, the Polish government concluded a commercial treaty with France ${ }^{15}$ in which it pledged to introduce a uniform law on unfair competition by 10 May 1926. As we know, the May coup halted legislative activity for a brief time, and the aforementioned law came into effect somewhat later.

In addition to economic conditions and the obligations of Poland in the international arena, the primary motive in favor of immediate establishment of uniform rules on unfair competition was the chaos that reigned in this field in Poland. ${ }^{16}$ Due to a lack of uniform legal solutions, activities permitted in one of the former partitions could have been prohibited in another. Such inconsistencies and even contradictions in the laws of the annexed partitions regarding unfair competition did not serve the development of industry and trade, weakening the fundamental rights of confidence in the law and trust by the citizen towards the state.

\section{III.}

The first steps by the newly-soverign Polish authorities in the fight against manifestations of unfair competition were the decrees of the Head of State of 4.02.1919, imposing new regulations on the protection of patents, designs, drawings and models, and trademarks. ${ }^{17}$ These decrees were replaced by the Law of 5.02.1924 on the protection of inventions, designs and trade marks (Journal of Laws, No 31, item 306). A bit of protection against unfair competition was also provided by art. 34 of the Decree of 7.02 .1919 on the trade register (Journal of Laws, No. 14, item 164).

It quikcly became clear, however, that these measures were not enough to combat this phenomenon through legal mechansims protecting

\footnotetext{
${ }^{12}$ Dz. U. RP $1920 \mathrm{nr}$ 110, poz.728 (Journal of Laws 1920, No 110, item 728).

${ }^{13}$ Dz. U. RP $1922 \mathrm{nr}$ 8, poz. 58 (Journal of Laws 1922, No 8, item 58)

${ }^{14}$ Union Internationale pour la protection de la propriete industrielle: Actes de la conference reunie a la Haye du 8 octobre au 6 novembre 1925, (1926) Berne 609.

${ }^{15}$ Dz. U. RP $1925 \mathrm{nr}$ 67, poz. 468 (Journal of Laws 1925, No 67, item 468).

${ }^{16}$ The same arguments were raised during the parliamentary debates on the Act. Senator Jackowski - the rapporteur of the Senate Legal Commission - proposed enactment of the Act during the $134^{\text {th }}$ session of the Senate; see: Stenographic Report of the $134^{\text {th }}$ Senate session of 23.07.1926, p. 38 - 39. Member of Parliament Chełmoński - the rapporteur of the Parliamentary Legal Commission - also presented the reasons for the adoption of this law during the $289^{\text {th }}$ parliamentary session; see: Stenographic Report of $289^{\text {th }}$ session of Sejm on 01.07.1926, p. 24

17 The decree on patents for inventions (Dz. U. RP, nr 13, poz.137), the decree on the protection of designs and models (Dz. U. RP, nr 13, poz.138), the decree on the protection of trademarks (Dz. U. RP, nr 13, poz.139). Earlier, the decree of 13.12.1918 established the Patent Office (Dz. U. RP, nr 21, poz.66), whose regulations were changed by the Law of 02.08.1919 on the subject of changes in the decree of the Head of State of 13.12.1918 on the Patent Office (Dz. U. RP, nr 67, item. 410).
} 
only parcitular entities (enterprises, trade marks, etc.). There was a need for new legal norms in the form of a separate statute. ${ }^{18}$

Analysing the origins of the Polish Act on combating unfair competition, one can not ignore the draft Law on industrial and commercial exclusivity of 17.03.1922. ${ }^{19}$ The author of this project was professor Fryderyk Zoll. ${ }^{20}$ Although the legislation did not enter into force, there were some outlines of the legal structure on which the basic concepts underlying the Act on combating unfair competition would be based. ${ }^{21}$ The links with the draft law on industrial and commercial exclusivity combating certain forms of unfair competition were clearly evident in the justification of this project as well. ${ }^{22}$

The final wording of the Act on combating unfair competition began to emerge in early January $1926^{23}$, when the Polish government entrusted the earliest possible drafting of the bill to professor F. Zoll. This haste resulted from the aforementioned treaty with France, according to which the statute was to be put into effect by May 10, 1926.

The result of Zoll's work was a project consisting of two parts, entitled "Law on the rights of enterprises and unfair competition". Part one, entitled "The rights of enterprises", laid down the concept of the company, its registration, the conditions for transfer of ownership from one person to another, and the establishment of pledges by contractual and judicial means as well as during enforcement proceedings against an enterprise. ${ }^{24}$ Part two, "On unfair competition", concerned unlawful acts of repression, which were generally regarded as actions affecting the personal right of a trader.

In mid-March 1926, Zoll sent his proposal in this form to the Commercial Law Section of the Codification Commission, headed by Professor A. Doliński. In April 1926, during debate on the bill, the Commercial Law Section came to the conclusion that the first part of the project (The rights of enterprises) was not complete ${ }^{25}$, and, with the consent of the author, further work on it was postponed until the deliberations on the Commercial Code. Further work was carried out on the second part of the bill, which had gained recognition in the eyes of the members of the Commercial Law Section. The deliberations led by the President of the Section, A. Doliński, lasted a week, and the appointed reporter was professor $\mathrm{T}$. Dziurzyński. Due to the inclusion of criminal laws in the draft, professor J. Makarewicz was invited to participate in the deliberations. Three readings

\footnotetext{
${ }^{18}$ Mayzel (n 11) 195.

${ }^{19}$ Sejm Print (1922) 3407 - Law of 1922 on industrial and commercial exclusivity.

${ }^{20}$ Fryderyk Zoll (1865 - 1948) professor of the Jagiellonian University, a prominent expert on intellectual property rights. Creator of the Law against Unfair Competition of 02.8.1926, the Copyright Act of 29.03.1926 and the Regulation on the protection of inventions, designs and trademarks of 05.02.1924.

21 The project did not include the concept of the enterprise in a 'pure' form, but some of its constituent elements can be seen in Article 8 of that project, under which a patent can not be disposed of separately from the company.

${ }^{22}$ See: Annex 2 to the Legislative Sejm Print (1922) 3407 38-39

${ }^{23}$ A Kraus, F Zoll, Polska ustawa o zwalczaniu nieuczciwej konkurencji z objaśnieniami (Poznań 1929) 1.

24 Zoll, 'Projekt ustawy o zwalczaniu nieuczciwej konkurencji' (n 11)' 127.

${ }^{25}$ See closer: Kraus, Zoll, (n 23) 4-5.
} 
were held, during which the project underwent numerous but insignificant changes. $^{26}$

A bill entitled "The law against unfair competition", adopted by the Commercial Law Section, was submitted to the Bureau of the Codification Commission, which, after adoption of the draft then sent it to Minister of Justice, S. Piechocki. On 30 April 1926, during the 27th meeting of the Council of Ministers, a draft law was passed on combating unfair competition; however, any amendment had to be agreed on by the Minister of the Interior and Minister of Agriculture and National Goods, whereas other interested ministers were to consult with the Minister of Justice on such matters. ${ }^{27}$ In fact, the Council of Ministers did not make any changes, and the draft law on combating unfair competition went to the Parliament in the form of Parliament Printing No. 2448 of 7.05.1926. Historical events (the May coup) stopped the path of the legislation for a few weeks.

\section{IV.}

Finally, the Law against unfair competition was passed by Parliament on August 2, $1926^{28}$, published 25 September 1926, and entered into force on 10 October 1926 (Journal of Laws, No. 96, item 559). ${ }^{29}$ Some provisions of

\footnotetext{
26 ibid 5.

${ }^{27}$ Records of the Office of the Council of Ministers, edition 33, p. 246.

${ }^{28}$ On 01.07.1926 there was a meeting of the Sejm, and the agenda for debate on the report provided for consideration by the Legal Commission of the draft law on unfair competition. Members of Parliament Sommerstein, Feldman and Hartglas suggested some amendments to the act, which were rejected by the Sejm. The Act was adopted on its second reading as proposed by MP Chełmoński, who presented the proposal of the Parliamentary Legal Commission to adopt the draft from the Codification Commission with a few minor modifications. Because of the opposition of MP Hartglas, that day there was no further work on the Act; see closer: stenographic report of $289^{\text {th }}$ session of the Sejm on 01.07.1926.

A third reading and adoption of the bill in parliament took place at the next session of the Sejm. More amendments were reported, of which only one was adopted; see closer: stenographic report of $290^{\text {th }}$ session of the Sejm on 05.07.1926.

During the work on the bill in the Senate on 23.07.1926 a number of amendments from the Legal Commission of the Senate were introduced into the text of the Act, which the Parliament partially adopted on 02.08 .1926 ; see closer: stenographic report of the $134^{\text {th }}$ Senate session on 23.07.1926, and stenographic report of $299^{\text {th }}$ session of the Sejm of 02.08.1926. In addition, during the sitting of the Senate, Senators Adelman and Ringel tried to introduce their amendments. There was also a proposal by Senator Średniawski of a referral to the Law Commission in the absence of a statute of records relating to counterfeiting of goods. This proposal was, however, rejected.

During parliamentary work on the Law, issues that reflected the problems of interwar Polish society (social strife and religious animosities) were revealed. Enactment of the Act was accompanied by intense debate between deputies and senators about the need to give statutory protection to citizens of Jewish faith, and others vulnerable to boycotts of their goods. MP Hartglas and Senator Ringel tried unsuccessfully to amend, among others, Article 3 of the Act, whose purpose was to establish civil penalties for "public incitement not to enter into a transaction with a company or a certain category of enterprises".

${ }^{29}$ Before the Act went into force, the courts also recognized cases where the facts were based on unfair competition. However, few of these cases were published. See: Supreme Court Judgement of 05.12.1924, C 293/24 [in:] (1925) Przegląd Prawa Handlowego 497-498; ruling of the Supreme Court of 12.11.1926, C 207/26 [in: ] (1927) Orzecznictwo Sądów Polskich 19-20; ruling of the Court of Appeal in Warsaw of 16.01.1927, Ac 213/26 [in:] (1927) Przegląd Prawa Handlowego 410-414; ruling of the District Court in Warsaw of
} 
the bill, especially those introduced as amendments by the Senate, met with sharp criticism. ${ }^{30}$

The most important, and quite reasonable, criticism against the solutions contained in the Polish law was the complete abolishment of the German law on unfair competition from 1909 (article 19 of the Polish Act of 1926). The above legislation nullified the provisions on sales ${ }^{31}$ contained in the German law (§ 7-10). Consequntly, this led to the hollowing out of prof. Zoll's concept, which had assumed that the rules on unfair competition stated in the existing laws world continue to remain in force, as long as they were directed against acts unregulated by the Polish statute (Article 15 of the Act and Article 14 of the draft of the bill). This weakened the internal cohesion of the Polish law. In addition to destabilization of trade (dumping became legal in the territory of the former Prussian annexation after the entry into force of the Polish law), this solution could also be accused of inconsistency, since the principles of rational legislative policy in this situation required the repeal of similar provisions in the Austrian Law on sale of 1895 with the immediate issue of a uniform act governing this issue throughout the Polish state. That did not happen, and the rules about sales in the Austrian law remained in force. ${ }^{32}$

Another disadvantage of the repeal of the German law on unfair competition was the weakening of the position of the victim associated with the loss of $\S 25$. There was initially no such legislation in our statute, thus the courts required the victim to demonstrate the conditions of $\S 935$ and 940 of the German civil procedure, that is, the likelihood of existence of a claim and danger. ${ }^{33}$

The German law of 1909 allowed only the announcement of the sale of goods coming from the assets of an enterprise undergoing liquidation. After its abolition, it also permitted the practice of publishing the sale of goods not originating from such assets. ${ }^{34}$ This did not benefit honest trade, and opened the field to a wide range of behavior constituting unfair competition.

Another serious problem was the regulation contained in Article 11, which predicated the investigation of claims of the acts referred to in Articles

04.02.1925, II. 2. 1231/24 [in:] (1925) Przegląd Prawa Handlowego 248-250; ruling of the District Court in Warsaw of 08.01.1926, II. 3. C 859/25 [in:] (1926) Przegląd Prawa Handlowego 123-125

${ }^{30}$ Also, by prof. Zoll, see: idem, 'La "novelle" relative à la loi polonaise du 2 aout 1926 concernant la repression de la concurrence deloyale' (1928) 1 Propriété industrielle 19 - 20; idem, 'Zur Charakteristik des neuen polnischen Gesetzes vom 2. August 1926 betreffend die Bekämpfung des unlauteren Wettbewerbes' (1927) 2 Ostrecht 123-124; idem, ,Novelle zum Gesetze vom 2. August 1926, betreffend die Bekämpfung des unlauteren Wettbewerbes' (1927) 1 Zeitschrift für Ostrecht 1155-1156.

${ }^{31}$ For detail about sales, see: J Hryniewiecki, 'Wysprzedaże towarów' (1926) 15 Świat Kupiecki 310-312.

32 Regulations applying to the decree of Council of Ministers of 14 March 1928 about sales made in trade (Journal of Laws 1928, No 41, item 395) were in force.

33 J Hryniewiecki, 'O konieczności uzupełnienia ustawy z dnia 2.8.1926 r. o zwalczaniu nieuczciwej konkurencji’ (1927) 8 Świat Kupiecki 141; H Willenbücher, Das Zivilprozess und Zwangsvollstreckungsverfahren (Berlin 1909) 398.

${ }^{34}$ Argument a contrario from Article 6 Paragraph 1 of the Polish Act 
6-8 under civil law on prior criminal proceedings. ${ }^{35}$ The appropriateness of penalizing attempts at committing the crimes listed in the Act was also recognized. ${ }^{36}$

In addition, there was no shortage of views critising the carelessness of the legislator in the legislative process of passing the Act. The basis of the criticism was the omission of the material jurisdiction of the court in Article 12 in the event of violation of Article $7 .{ }^{37} \mathrm{~A}$ similar error was committed in Article 17, where no limitation period of the offence in Article 7 was specified. $^{38}$

Another disadvantage of the law was observed in the lack of an expressis verbis statement determining which acts of unfair competition in the criminal section of the Act constituted a crime, and which were only minor (non-criminal) offenses. There were also critics offended by the nomenclature used in the Act. They argued that phrases such as "encroachment on somebody's customers" or "user of signs" were alien to the Polish legal language. ${ }^{39}$ As we know, the problem of linguistic correctness of legislation was of major concern to Polish lawyers of the interwar period.

There was an obvious, pressing need for changes in the law, thus it was soon amended by the Regulation of the President of the Republic of Poland on 17 September 1927 (Journal of Laws, No. 84, item. 749) ${ }^{40}$ and its consolidated text was announced by the Regulation of the Minister of Industry and Trade dated July 9, 1930 (Journal of Laws 1930, No. 56, item. 467).

\section{V.}

Until 1939, legal doctrine seriously dealt with issues of unfair competition, which was reflected in the very valuable literature on the subject. Also, courts often resolved disputes on the basis of the Act of 1926, resulting

\footnotetext{
${ }^{35}$ Addition to the text of the Law Articles 19 and 11 were performed by Senate amendments, then adopted by the Parliament, without the knowledge of prof. Zoll. These amendments greatly distorted the meaning of the Act and the pursuit of unfair competitors committing fraud in several important aspects of the competitive struggle

${ }^{36}$ These allegations came from practitioners coming from the territory of the former Prussian annexation. The strongest demands for impairment of certain solutions in the Polish Law and proposals for their removal were provided by J Hryniewiecki; see: idem, 'O konieczności uzupełnienia ustawy' (n 33) 141-143. The Association of Lawyers in Poznan and the Association of Mercantile Societies in Poznan had some reservations about this law as well ${ }^{37}$ In the draft of the law contained in Sejm Print No. 2448 of 07.05.1926 the jurisdiction was determined. This offense was placed under the jurisdiction of county courts, while in the former Russian annexation - the magistrates" courts

${ }^{38}$ In this case, Sejm Print No. 2448 of 07.05.1926 (in Articles 16) determined the year-long limitation period for an action under Article 7

${ }^{39}$ M Jastrzebski, 'Kwiatek ustawodawstwa' (1926) 45 Prawda 5; J Namitkiewicz, 'Uwagi nad polską ustawą o zwalczaniu nieuczciwej konkurencji' (1927) 7 Przegląd Prawa Handlowego 301-302; A Peretz, 'Z powodu ustawy o zwalczaniu nieuczciwej konkurencji' (1926) 9 Przegląd Prawa Handlowego 410.

${ }^{40}$ The most glaring errors were removed and corrected at the revision of the bill. However, some problems relating to amendments of the Senate and their negative consequences could not be prevented. This related in particular to the total abolition of the binding force of the German Law from 1909. Failure to do so would have led to its repeat promulgation
} 
in detailed writings dealing with unfair competition. ${ }^{41}$ However, before the entry into force of the Law against unfair competition, the Polish courts had only occasionally dealt with issues of unfair competition rights and intangible property. This is confirmed by a statistical analysis of activity of the common courts hearing civil and criminal cases, which shows that in 1925, out of 8106 civil cases received by the Departments of Commerce and District Courts, only 13 related to intangible property rights. This is only $0.16 \%$ of all cases. The situation was slightly better in 1926, the first year of the Act being in effect. Then, out of the 5378 cases registered in the Departments of Commerce and District Courts, 14 related to intangible property rights $(0.26 \%) .{ }^{42}$ Despite painstaking investigations, I was unable to acquire statistics illustrating this issue in the other years when the Act was in force. ${ }^{43}$ However, analysis of the subject conclusively shows that the number of such cases was dramatically higher than before the entry into force of the Act of 1926.

There is no doubt that the system of unfair competition regulation created by prof. F. Zoll grew out of the achievements of continental legal thought. However, it can not be attributed either to the French nor the German model of unfair competition law. ${ }^{44}$ This was in effect an original expression of Polish legal thought, however, one partly related to the corresponding French and German legal thought. The Polish and French systems had in common the civil law method of combating unfair competition using the structure of a subjective right. ${ }^{45}$ The existence of general clauses in the law and the separation of criminal law brought the Polish system of combating unfair competition closer to the German system, which served as a starting point for the Polish law. Furthermore, analyzing the Polish Act of 1926 and its corresponding German Act of 1909, it is worth mentioning some similarities in the regulation of criminal law, particularly the similar catalog of acts prosecuted criminally. This demonstrates that prof. Zoll, applying German solutions, drew inspiration from the examples and experiences of legislation with a long history of successful repression of unfair competition.

\footnotetext{
${ }^{41}$ Despite everything, however, there was a perception that the majority of cases concerning unfair competition were not sent to courts. In the opinion of A. Lutwak, the reason for this was the lack of financial resources of Polish entrepreneurs to undertake "often difficult, lengthy and costly" litigation, and a relatively poorly-developed sensitivity and respect for values such as merchant reputation, corporate reputation and the dignity and tradition of a company. See: A Lutwak, 'Nieuczciwa konkurencja przez odstraszanie odbiorców i podrywanie kredytu' (1931) 3 Głos Prawa 115-116.

42 Source: 'Statistics of courts in general civil and criminal matters' (1930) Volume XXXVIII The Statistical Office of the Republic of Poland 8, table 3.

43 The sources for the search were the statistical yearbooks, industry statistics, business statistics and trade statistics of courts.

44 The French system was characterized by a lack of statutory regulation of this matter, combating unfair competition by civil methods using a subjective right. The German system was based on case reports specified in the law of unfair competition on acts of calculation, supported by the General Clause. It was a criminal law method of adjustment

${ }^{45}$ In France, this was the law for customers, in Poland - for the ownership of a company as an intangible good
} 
The Polish law on combating unfair competition met with interest the and approval of the era's representatives doctrine. ${ }^{46} \mathrm{~T}$. Blumenfeld's review ${ }^{47}$ of commentary on the law of unfair competition, written by A. Kraus and F. Zoll and expressed in a warm though occasionally polemical tone, was published in 1930 in the Review of Law and Administration (Przeglad Prawa $i$ Administracji) - a prestigious and opinion-shaping legal journal. The review positively evaluated Zoll's concepts, and as a consequence approved the enacted statutory solutions. A similar evaluation was also presented in a valuable monograph by $\mathrm{T}$. Blumenfeld, "Clientle as the subject of trade and legal protection" ("Klientela jako przedmiot obrotu i ochrony prawnej"). ${ }^{48}$ Prof. Zoll's achievements in the fight against unfair competition and his statutory solutions are highly praised in the introductory to a publication titled "The Act of 2 August 1926 on combating unfair competition" ("Ustawa z dnia 2-go sierpnia 1926 r. o zwalczaniu nieuczciwej konkurencji") by M. Howorka. This work presented a small commentary on the Act and contains a number of valuable suggestions for its interpretation. Positive evaluations relating to this Act can also be found in Polish post-war legal doctrine. ${ }^{49}$

Interest in the Law and a positive evaluation of its solutions could also be observed in lay publications. Evidence of this was the article titled "The Act on combating unfair competition" ("Ustawa o zwalczaniu nieuczciwej konkurencji") by Ś. Baudouin de Courtenay, published in the "Industry and Trade" ("Przemyst $i$ handel") magazine of $1926 .{ }^{50}$ The positive attitude of the aforementioned author to the Act can be verified by his article titled "Protection of an enterprise" ("Ochrona przedsiębiorstwa") published in the book "Economic Policy" ("Polityka gospodarcza"). ${ }^{51}$

The provisions of Polish law, as well as its theoretical concepts, were also quoted when discussing other issues connected in some way with unfair competition. $^{52}$

Significant interest and approval of F. Zoll's views on combating unfair competition were also expressed by international opinion. Prof. Zoll presented the principles of his theory of unfair competition at the International

\footnotetext{
46 The determined attacks on the bill occurred infrequently, and came mostly from people who did not have such well-established authority and expertise in this area to establish a positive image of this law.

47 T Blumenfeld, 'Rozprawy i zapiski literackie' [1930] Przegląd Prawa i Administracji 436440. For another positive review on the law on unfair competition, see: M A, 'Rozprawy i zapiski literackie' [1929] Przegląd Prawa i Administracji 496-497.

48 Although the author contrasted the theories of Zoll with his own ideas, he welcomed the statutory solutions.

${ }^{49}$ L Górnicki, 'Wpływ obcych ustawodawstw i doktryny prawa na polską kodyfikację prawa prywatnego w Drugiej Rzeczypospolitej' (2005) 13 Zeszyty Naukowe Uniwersytetu Jagiellońskiego. Towarzystwo Biblioteki Słuchaczów Prawa. Zeszyty Prawnicze. 'Korzenie i tradycje współczesnego prawa cywilnego w zjednoczonej Europie', edited by A Karabowicz and M Stus, 78.

${ }^{50}$ (1926) 42 Przemysł i handel 1260-1261.

${ }^{51}$ Polityka gospodarcza (Warsaw 1928) 67-83 and 87.

52 By way of example, see: K Apołłow, 'Ustawowa ochrona przedsiębiorcy przed utratą klienteli' (1937) 1 Przegląd Prawa Handlowego 17-19; I Rosenblüth, 'Znaczenie prawne ruchu przedsiębiorstwa' (1930) 8 Przegląd Prawa Handlowego 359 or A Chełmoński, 'Przegląd ustawodawstwa w dziedzinie prawa cywilnego i handlowego za rok 1925 i 1926' (1928) Rocznik Prawniczy Wileński 275-278; idem, 'Rejestr handlowy na tle dekretu z d. 7 lutego 1919 r.' (1929) Rocznik Prawniczy Wileński 764-775.
} 
Congress of Experts in Geneva in May $1924^{53}$ and during the International Congress for the Revision of the Paris Convention in the Hague in October 1925, which met with approval from foreign observers. ${ }^{54}$ The speech by Zoll, contrary to custom, was published in its entirety in the documents of the Hague Conference ${ }^{55}$, which was further evidence of the respect given to the theoretical concepts of F. Zoll.

The Polish Act aroused interest in France and Germany ${ }^{56}$, countries that prided themselves on a much longer tradition of combating unfair competition. A translation of the Polish law into French was published in "Propriété Industrielle" in January 1927, and into German in "Zeitschrift für Ostrecht" in February 1927. ${ }^{57}$ In addition, in the reputable foreign legal press and other publications, articles written by prof. Zoll were printed explaining the nature and theoretical constructions in Polish law, as well as presenting his views on these issues. ${ }^{58}$ It is worth mentioning a thorough discussion of the Act and its highly positive evaluation by Ph.D. R. Kuratow-Kuratowski ${ }^{59}$ from the University of Paris.

As proof of the interest in problems of unfair competition in Poland and the great respect for the views of prof. F. Zoll, one can cite a translation into German of his opinion on "The 'Maggi' producer's exclusive right to the use of specific bottles in the trade of soup spices"60, and also reporting on important judicial decisions and their justifications in the German legal journal "Zeitschrift für Ostrecht". ${ }^{61}$

${ }^{53}$ The agenda and summary of prof. Zoll, see: idem, 'Zwalczanie nieuczciwej konkurencji jako zadanie Ligi Narodów' (1924) 25 Gazeta Administracji i Policji Państwowej 502-503 and (1924) 26, 522-524.

${ }^{54}$ See Report of the President of the Codification Committee, Rector Fr X Fierich, delivered at the joint meeting of the Legal Committee of the Sejm and Senate on 21 March 1927, [in:] Komisja Kodyfikacyjna Rzeczypospolitej Polskiej. Dział Ogólny, vol. 1, issue 10, Warsaw 1927, p. 271

${ }^{55}$ Union Internationale pour la protection de la propriété industrielle: Actes de la Conférence reunie a la Haye du 8 octobre au 6 novembre 1925, (1926) Berne 473-474.

${ }^{56}$ The Polish law on combating unfair competition was held by German doctrine to be progressive and modern - A Elster, A Pinner, 'Gesetz gegen den unlauteren Wettbewerb' (1927) Berlin 49.

${ }^{57}$ Kraus, Zoll, (n 23) 46.

${ }^{58} \mathrm{~F}$ Zoll, 'A propos de la loi polonaise du 2 aout 1926 concernant la repression de la concurrence deloyale' (1927) 4 Propriété Industrielle 64-68; idem, 'Das Schöpferische der Unternehmertätigkeit als Immaterialgut' (1927) 15 Danziger Wirtschaft Zeitung 230; idem, 'Zur Charakteristik' (n 30) 113-126.

59 R Kuratow-Kuratowski, 'La nouvelle legislation polonaise sur la repression de la concurence deloyale' (1927) 7-9 Bulletin Mensuel de la Societe de Legislation comparee 341-360.

${ }^{60}$ Rechts-Gutachten von Professor Dr. Fryderyk Zoll über das Recht der Firma Maggi zum ausschliesslichen Gebrauch von charakteristischen Suppenwürzeflaschen im Handel, Poznań 1932.

61 See: (1931) 3 Zeitschrift für Ostrecht 202-204, with discussion of the Supreme Court Judgment dated 04.05.1928 (III Kr. 404/27). This judgment became the basis for discussing the concept of enterprises and entrepreneurs in the Polish Act on combating unfair competition - SM Grzybowski, 'Der Begriff des Unternehmens und des Unternehmers im polnischen Gesetz über den unlauteren Wettbewerb' (1931) 3 Zeitschrift für Ostrecht 174180. 
After World War II, the Act on combating unfair competition, although in force ${ }^{62}$, was not actually applied in the judicial practice of common courts or of the State Economic Arbitration Panel (PAG). ${ }^{63}$ This was due to the total destruction of market mechanisms in the economy and rejection of prof. Zoll's theoretical structure - the right to an enterprise as an intangible good, which was the basis of the law. ${ }^{64}$ Moreover, considerable doubt as to the validity of the Law against unfair competition of 1926 was introduced by the Act of 19 April 1969 - Regulations introducing the Criminal Code (Journal of Laws No. 13, item 95). Article V § 1 of this Act rendered void special laws issued before 5 September 1939, including provisions on liability for crimes. There was a serious problem of interpreting on this basis whether the Act affected the whole of the law on unfair competition or only the section of the Act dealing with criminal responsibility. ${ }^{65}$ This uncertainty was clarified by the resolution of the Constitutional Court of 23 January 1991 (Journal of Laws No. 11, item. 45), which held that said Article repealed only the criminal provisions of the Act, with effect from 1 January $1970 .{ }^{66}$

In summary, the Act of 1926 laid the foundations for the modern repression of unfair competition, and its legal and theoretical concepts ${ }^{67}$ fully met the highest international standards of the time, and even determined the direction of development of other legislation. Later economic development, technological progress and Poland's international obligations necessitated the creation of a new act in 1993.

62 J Waluszewski, 'Moc i zakres obowiązywania ustawy o zwalczaniu nieuczciwej konkurencji' (1975) 4 Nowe Prawo 511-525. The author analyzed the two potential causes of loss of binding force of the Law against Unfair Competition of 1926: 1) desuetudo exemptions from the Act by its failure to comply with the implementation of the law, and 2) the possible non-compliance of the law with the principles of the new regime of socioeconomic and political development. In both cases he came to conclusions justifying the assertion of the law's binding force.

${ }^{63}$ The validity of the Law against Unfair Competition of 1926 was reaffirmed also by the judicature of the Supreme Court in its judgment of 14.6.1988, II CR 367/87, [in:] (1990) 9 Orzecznictwo Sądów Polskich, item 328, p. 703-705 and approving commentary by M Kępiński [in:] (1990) 9 Orzecznictwo Sądów Polskich, item 328, p. 705-707 and in the ruling of 25.10.1988, II CR 143/88 (unpublished).

${ }^{64}$ The situation was reversed by political changes in Poland in 1989. The new legal system brought about the need to reapply the Act. In this, period rulings based on the Act of 1926 began to appear again (see: ruling of Court of Appeal in Łódź dated 14.03.1991, I ACr 23/91 [in:] (1991) 11-12 Orzecznictwo Sądów Polskich, item 281, p. 533-535; ruling of Court of Appeal in Poznan dated 24.06.1992, I ACr 204/92 [in:] (1993) 2 Wokanda 30-32).

${ }^{65}$ There were also comments that Article V of the aforementioned Act related only to offenses under the Criminal Code of 1969, and therefore did not apply to acts of unfair competition contained in the Act of 1926, consequently leading to a request for further application of the law in the field without modifications. This view was represented by Z Żecki, 'Zwalczanie nieuczciwej konkurencji’ (1990) 10 Przegląd Ustawodawstwa Gospodarczego 149.

${ }^{66}$ Some of the drawbacks of the resolution were recognized by M Kępiński, 'Problemy ogólne nowej ustawy o zwalczaniu nieuczciwej konkurencji’ (1994) 2 Ruch Prawniczy, Ekonomiczny i Socjologiczny 1-2.

${ }^{67}$ Detailed solutions dealing with the theoretical concepts of the Act of 1926 were discussed by T Dolata, 'Ustawa o zwalczaniu nieuczciwej konkurencji z 1926 roku. Charakterystyka ogólna’ (2006) 2887 Acta Universitatis Wratislaviensis, Prawo CCXCVIII, 241-259. 